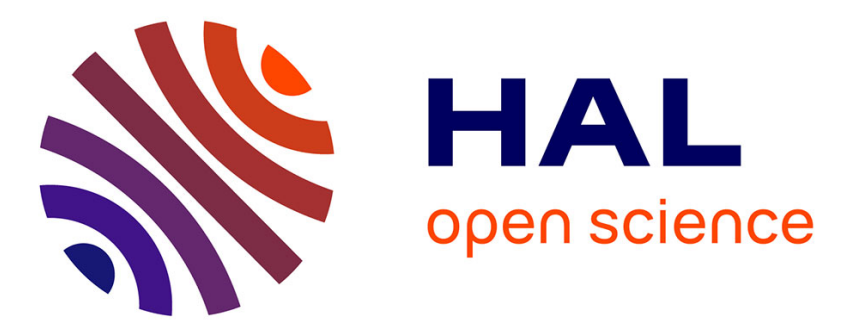

\title{
Selected growth factors and diffusing capacity of the lung for carbon monoxide in patients with systemic lupus erythematosus
}

Antoni Hrycek, Wladyslaw Pierzchala, Anna Oslawska-Dzierżęga, Pawel Cieślik

\section{To cite this version:}

Antoni Hrycek, Wladyslaw Pierzchala, Anna Oslawska-Dzierżega, Pawel Cieślik. Selected growth factors and diffusing capacity of the lung for carbon monoxide in patients with systemic lupus erythematosus. Rheumatology International, 2009, 30 (2), pp.175-179. 10.1007/s00296-009-0930-7. hal-00568284

\section{HAL Id: hal-00568284 \\ https://hal.science/hal-00568284}

Submitted on 23 Feb 2011

HAL is a multi-disciplinary open access archive for the deposit and dissemination of scientific research documents, whether they are published or not. The documents may come from teaching and research institutions in France or abroad, or from public or private research centers.
L'archive ouverte pluridisciplinaire HAL, est destinée au dépôt et à la diffusion de documents scientifiques de niveau recherche, publiés ou non, émanant des établissements d'enseignement et de recherche français ou étrangers, des laboratoires publics ou privés. 
Antoni Hrycek $^{1 ⿴ 囗 凶}$,Władysław Pierzchała ${ }^{2}$, Anna Osławska-Dzierżęga ${ }^{1}$, Paweł Cieślik ${ }^{1}$ Selected Growth Factors and Diffusing Capacity of the Lung for Carbon Monoxide in Patients with Systemic Lupus Erythematosus

(1) Department of Internal, Autoimmune and Metabolic Diseases, Medical University of Silesia, ul. Medyków 14, 40-752 Katowice, Poland and

(2) Department of Pneumonology, Medical University of Silesia, ul. Medyków 14, 40-752 Katowice, Poland

prof. Antoni Hrycek M.D., Ph.D.,

Address: ul. Tysiąclecia 86a/34, 40-871 Katowice, Poland

E-mail: genmar@ka.onet.pl

Tel: ++48322544807 


\begin{abstract}
The purpose of the study was to evaluate serum concentrations of selected growth factors and the diffusing capacity of the lung for carbon monoxide (DLCO) in 21 females treated for SLE. The control group consisted of 24 healthy women. Based on high-resolution computed tomography (HRCT), patients were allocated to a subgroup of 11 subjects (HRCT-negative) and a subgroup of 10 with pulmonary abnormalities (HRCT-positive). In HRCT-negative patients a significantly higher level of TNF- $\alpha$ as compared to the control was observed and positive correlation between TNF- $\alpha$ and bFGF was revealed in this subroup and in the total group of patients. DLCO was below the predicted value in 13 patients. No correlations between DLCO and growth factors concentrations were observed. DLCO reduction in asymptomatic, in respect to the respiratory system, SLE patients suggests a need for longterm monitoring of this parameter. The role of TNF- $\alpha$ in these patients requires further investigations.
\end{abstract}

Keywords: Systemic lupus erythematosus, Growth factors, Angiogenesis, Lung function parameters 


\section{Introduction}

Systemic lupus erythematosus (SLE) is organ nonspecific autoimmune disease where damage of organ structure and function is associated with action of different autoantibodies and deposition of immune complexes in tissues. The respiratory system can also become involved; the disease most frequently develops within the pleura, causes pulmonary interstitial changes, and damages of pulmonary vessels. Diaphragm dysfunction can occur and compromise the function of the respiratory system [1-3]. An ongoing autoimmune inflammatory process causes the activated immune-competent cells to release factors that initiate and support the inflammatory response. This may result in organ fibrosis including pulmonary lesions [4]. Angiogenesis, influenced by various stimulating and inhibiting growth factors, eg., vascular endothelial growth factor (VEGF) and its soluble receptors (sVEGF R1, sVEGF R2), and its disturbances, may also play a role in the above mentioned process $[5,6]$.

The purpose of the study was to assess serum concentrations of selected growth factors, and evaluate the diffusing capacity of the lung for carbon monoxide (DLCO) in SLE patients.

\section{Materials and methods}

The study was approved by the local independent bioethics committee and all subjects and controls were required to give consent.

\section{Patients and controls}

The investigations were carried out in 21 consecutive women with SLE (mean age $51 \pm 12.4$ years), with no symptoms of respiratory tract disease. All patients had already been treated from several months to several years. In the examined persons any pulmonary toxic medications have not been applied prior to the current therapy. The patients with occupational 
exposures for crystalline silica, solvents and pesticides were excluded. Pharmacotherapy included the following drugs applied as single or in various combinations: prednisone (510mg daily), azathiopirine (50-100 mg daily), cyclophosphamide (periodic administration 200 mg daily), cyclosporine A (50-100mg daily) and prolactin-suppressive drug-dopamine agonist- quinagolide (25-50 $\mu \mathrm{g}$ daily) [7]. Diagnosis was based on the criteria developed by the American Rheumatism Association (ARA) in 1982 [8], and then revised in 1997 [9]. The patients had 4 of 11 criteria for SLE; most with mild-to-moderate disease had SLE disease activity index (SLEDAI) of $<10$ score or slightly higher on qualification to study. Three or four organs were affected. Three subjects were cigarette smokers, the remaining 18 did not smoke. SLE seroactivity and screening tests for autoimmune disease were performed, including erythrocyte sedimentation rate, anti-DNA antibodies, antinuclear antibodies, anticardiolipin antibodies, and serum complement factor C3. Based on high-resolution computed tomography (HRCT) scans, patients were allocated to a subgroup of 11 patients with no lung or pleural lesions (HRCT-negative), and a subgroup of 10 with reticulonodular opacities mainly in the lower portion of the lungs, parenchymal enhancement or honeycomb pattern (HRCT-positive). The control group consisted of age and place of residence-matched 24 healthy women (mean age $51 \pm 15.3$ years) without pharmacotherapy whose blood tests were within normal range.

\section{Methods}

Laboratory measurements included serum levels of the following growth factors and soluble receptors: VEGF, sVEGF R1, sVEGF R2, basic fibroblast growth factor (bFGF), hepatocyte growth factor (HGF), transforming growth factor- $\beta 1$ (TGF $\beta 1)$ and tumor necrosis factor- $\alpha$ (TNF- $\alpha$ ). ELISA assays were performed using RayBio ${ }^{\circledR}$ or Diaclone kits on the $\mu$ Quant ${ }^{\mathrm{TM}}$ Microplate Spectrophotometer. Blood samples were collected between 7 and 8 am from 
patients after an overnight fast, randomly coded, and stored at a temperature of below $-70^{\circ} \mathrm{C}$. Subsequent investigations were performed as an open randomized blind trial.

Pulmonary function was assessed using the single-breath DLCO with normal value $\geq$ $80 \%$ of the predicted value [4]. DLCO percentage was expressed with correction for hemoglobin concentration and after simultaneously measured alveolar volume (VA) to calculate DLCO/VA index. Pulmonary function tests were performed by Masterlab spirometer (Masterlab E. Jaeger, Würzburg, Germany). Vital capacity (VC) was also checked using $80 \%$ of predicted value as the lower limit of normal.

The following investigation scheme was adopted: $1 /$ comparison of serum concentrations of selected cytokines between the patient group ( 21 female patients with SLE) and the control (24 healthy women), 2/ comparison of serum concentrations of selected cytokines between HRCT-negative SLE subgroup $(n=11)$ and the control, 3/ comparison of serum concentrations of selected cytokines between HRCT-positive SLE subgroup $(n=10)$ and the control, 4/ analysis of relationships between particular serum cytokine concentrations, 6/ analysis of relationships between DLCO and cytokine concentrations, 7/ comparison of DLCO frequency below $80 \%$ predicted value between HRCT-positive and HRCT-negative subgroups.

\section{Statistical analysis}

The results were subject to normal distribution analysis by the Shapiro-Wilk's test. Arithmetic means (X) and standard deviations (SD) were calculated. A test for equality of variances was carried out prior to a comparison of group/subgroup means. Snedecor's F test for the difference of two variances was used. When variable distribution was normal and equality of variances was confirmed, further calculations were made using parametric Student's t test of unrelated variables. When the condition of normal distribution did not 
apply, further analyses were carried out with a nonparametric test. Relationships between parameters investigated were tested by Pearson's analysis; correlation coefficients were calculated to determine relationships between cytokine concentrations, and between DLCO and cytokine concentrations. Fisher's exact test was applied to determine the DLCO frequency defined as the percentage of individuals with value $<80 \%$ of predicted one in relation to the results of HRCT. Difference between mean values was considered statistically significant at $\mathrm{p}<0.05$, and highly significant at $\mathrm{p}<0.001$.

\section{Results}

Mean serum VEGF, bFGF, HGF, and TNF- $\alpha$ concentrations of SLE patients (3494.90 $\pm 1879.35 \mathrm{pg} / \mathrm{mL}, 1432.18 \pm 3030.80 \mathrm{pg} / \mathrm{mL}, 1478.14 \pm 1258.92 \mathrm{pg} / \mathrm{mL}$, and $19.24 \pm 22.33$ $\mathrm{pg} / \mathrm{mL}$, respectively) were higher than in the control $(2869.42 \pm 1625.70 \mathrm{pg} / \mathrm{mL}, 869.28$ $\pm 1737.60 \mathrm{pg} / \mathrm{mL}, 1205.89 \pm 531.70 \mathrm{pg} / \mathrm{mL}$, and $13.38 \pm 11.85 \mathrm{pg} / \mathrm{mL}$, respectively) while sVEGF R1, sVEGF R2 and TGF $\beta 1(0.15 \pm 0.08 \mathrm{ng} / \mathrm{mL}, 9046.79 \pm 4070.94 \mathrm{pg} / \mathrm{mL}, 11.08$ $\pm 5.01 \mathrm{ng} / \mathrm{mL}$, respectively) were lower as compared to the control subjects $(0.24 \pm 0.23$ $\mathrm{ng} / \mathrm{mL}, \quad 9541.52 \pm 5350.57 \mathrm{pg} / \mathrm{mL}, 12.73 \pm 4.38 \mathrm{ng} / \mathrm{mL}$, respectively). However, the differences between mean values of the parameters did not reach the level of statistical significance. Only TNF- $\alpha$ differences got near statistical significance.

The HRCT-negative subgroup of SLE patients had a significantly higher level of TNF$\alpha$ than the control. No statistically significant differences were revealed as to the concentrations of other cytokines investigated (Table 1). HRCT-positive subjects had the lowest TNF- $\alpha$ levels among the examined groups/subgroups. However, no statistically significant differences were found between HRCT-positive patients and the control when serum concentrations of growth factors and soluble receptors were compared ( Table 1).

$>$ Table $1<$ 
In the whole patient group and HRCT-negative subjects a statistically significant positive correlation between TNF- $\alpha$ and bFGF was revealed (Table 2). No similar correlations were seen in HRCT-positive patients (Table 2).

$>$ Table $2<$

Abnormal DLCO was found in 13 of 21 SLE subjects; 7 patients belonged to HRCTpositive, and 6 patients to HRCT-negative subgroup. The respective mean values in the whole patient group, HRCT-negative and HRCT-positive subjects were $78.02 \pm 19.05 \%, 80.27$ $\pm 17.47 \%$, and $75.55 \pm 21.31 \%$. No significant difference in frequency of DLCO below $80 \%$ was observed between HRCT-positive and HRCT-negative subgroups of patients ( $\mathrm{p}=0.659$ ). No statistically significant differences were found in the whole patient group and in HRCT subgroups as to correlations between DCLO, cytokines and soluble receptors concentrations (Table 3).

$>$ Table $3<$

Mean VC of the whole patient group was $100.58 \%$; in HRCT-positive and HRCT-negative subgroups the values were $99.76 \%$ and $103.14 \%$, respectively. Values below $<80 \%$ were only seen in 2 patients.

\section{Discussion}

There are only few studies investigating pulmonary function of asymptomatic in respect to respiratory system, patients treated for $\operatorname{SLE}[3,10,11]$. As it was mentioned before, the respiratory system is the area where autoantibodies and / or immune complexes may cause damage. Consequently fibrosis may be initiated both as a result of autoimmune inflammatory processes and processes causing damage to the pulmonary vasculature. In angiogenesis, vascular endothelium with activating and inhibiting factors play the crucial role [12]. We 
therefore decided to evaluate serum concentrations of selected growth factors, which are key regulators of angiogenesis.

Our results did not show any significant differences in serum VEGF, sVEGF R1, sVEGF R2, TGF $\beta 1$, HGF, and bFGF concentrations between the study subjects and the controls. Only TNF- $\alpha$ levels proved significantly higher in HRCT-negative patients with SLE. The function of TNF is inhibited by its soluble receptors (s TNF R) [13, 14]; thus, lower concentrations thereof should enhance TNF activity. Our previous results had not revealed essential changes in STNF Rs concentrations in the course of therapy for SLE [7]. Therefore we suppose that higher serum levels of TNF- $\alpha$ observed in the present study may be the effect of higher production of this factor in SLE. The lowest TNF- $\alpha$ was observed in HRCTpositive patients and it remains unaccounted for. It may be that, following the development of lesions, the levels and activity of TNF- $\alpha$ normalize. The significant positive correlation between serum TNF- $\alpha$ and bFGF levels seen in the whole patient group and HRCT-negative subjects and the lack of similar correlation in HRCT-positive patients might support such hypothesis in the light of the role of bFGF in fibrosis [15]. The results concerning the level of TNF- $\alpha$ in our study differ from the earlier ones obtained by other authors who observed increased serum level of this factor in SLE patients $[16,17]$ especially in SLE subjects with pulmonary involvement [17]. The demonstrated differences could be partially explained by lower disease activity in our patients (calculated on the day of blood sampling SLEDAI score was $<10$ or slightly higher) [18]. It should be stressed now, that the group of our patients consisted of SLE treated subjects and it is known that the applied therapy can modify the serum levels of the analysed growth factors.

Basic FGF is one of the fibroblast growth factor families and is mitogenic for a variety of cells including fibroblasts and is also a known chemotactic and as it was mentioned angiogenic factor $[19,20,21]$. We did not observe statistically significant differences between 
its serum levels in the whole patient group and subgroups when compared to the control, which remains in accordance with the results of earlier reports [20, 22]. It is worth mentioning however, that the mean level of this factor was higher in SLE patients than in the controls.

It is believed that a decrease in DLCO is the best indicator of compromised pulmonary function (1). DLCO reduction is observed in diseases with alveolar gas exchange surface reduction and damage to pulmonary capillaries [23]. Our results concerning DLCO are in accordance with earlier studies, where reduced values of the parameter were demonstrated in SLE patients both with and without fibrotic lesions on HRCT scans [1]. It should also be noticed that no statistically significant correlations were seen between DLCO and serum growth factors concentrations in our patients with SLE. Reduction of DLCO in free of the respiratory symptoms SLE patients suggests a need for long-term monitoring of the parameter, starting at diagnosis and further on not only in periodic aspect of the disease activity assessment but also in periodic assessment of the respiratory system function.

We conclude that in treated patients with mild-to-moderate systemic lupus erythematosus, the reduced diffusing capacity of the lung for carbon monoxide is not associated with serum concentrations of examined angiogenic factors and with pulmonary abnormalities determined by high-resolution computed tomography. The role of TNF- $\alpha$ in asymptomatic, as far as respiratory system is concerned, systemic lupus erythematosus patients requires further research. The investigations would have to be aimed at repeat evaluation of the lung lesion development in the above-mentioned patients group, and should be scheduled as a long-term study. 


\section{References}

1. Nakano M, Hasegawa H, Takada T, Ito S, Muramatsu Y, Satoh M, Suzuki E, Gejyo F (2002) Pulmonary diffusion capacity in patients with systemic lupus erythematosus. Respirology 7:45-40 Medline. doi:10.1046/j.1440-1843.2002.00361.x

2. Ooi GC, Nagan H, Peh WCG, Mok MY, Ip M (1997) Systemic lupus erythematosus patients with respiratory symptoms: the value of HRCT. Clin Radiol 52:775-781 Medline. doi:10.1016/S0009-9260(97)80159-6

3. Paran D, Fireman E, Levartovsky D, Elkayam O, Litinsky I, Caspi D, Koifman B, Keren G, Schwarz Y (2007) Pulmonary dysfunction in systemic lupus erythematosus and antiphospholipid syndrome patients. Scand J Rheumatol 36:285-290 Medline. doi:10.1080/03009740601153816

4. Dziankowska-Bartkowiak B, Waszczykowska E, Żebrowska A, Sysa-Jędrzejowska A (2005) Pulmonary involvement in systemic sclerosis patients and serum level of vascular endothelial growth factor (VEGF). Przegl Dermatol 92:37-43.

5. Robak E, Kulczycka L, Tomczak J, Sysa-Jędrzejowska A (2006) The role of angiogenesic cytokines in systemic lupus erythematosus pathogenesis. Acta Haematol Pol 37:47-59.

6. Dziankowska-Bartkowiak B, Waszczykowska E, Dziankowska-Zaboroszczyk E, de GraftJohnson JE, Zalewska A, Łuczyńska M, Nowak D (2006) Decreased ratio of circulatory vascular endothelial growth factor to endostatin in patients with systemic sclerosisassociation with pulmonary involvement. Clin Exp Rheumatol 24:508-513 Medline.

7. Hrycek A, Cieślik P, Tustanowski J, Nowak S, Jedynak P (2001) Selected serum cytokines in systemic lupus erythematosus treated with quinagolide. Lupus 10:424-430 Medline. doi:10.1191/096120301678646173

8. Tan EM, Cohen AS, Fries JF, Masi AT, McShane DJ, Rothfield NF, Schaller JG, Talal N, Winchester RJ (1982) The revised criteria for the classification of systemic lupus erythematosus. Arthritis Rheum 25:1271-1277 Medline. doi:10.1002/art.1780251101

9. Hochberg MC (1997) Updating the American College of Rheumatology revised criteria for the classification of systemic lupus erythematosus. Arthritis Rheum 40:1725 Medline. doi:10.1002/art.1780400928

10. Trapani S, Gamiciottoli G, Ermini M, Castellani W, Falcini F (1998) Pulmonary involvement in juvenile systemic lupus erythematosus: a study on lung function in patients asymptomatic for respiratory disease. Lupus 7:545-550 Medline. doi:10.1191/096120398678920631

11. Kakati S, Doley B, Pal S, Deka UJ (2007) Pulmonary manifestations in systemic lupus erythematosus (SLE) with special reference to HRCT. Assoc Physicians India 55:839841.

12. Jośko J, Gwóźdż B, Jędrzejowska-Szypułka HM, Hendryk S (2000) Vascular endothelial growth factor (VEGF) and its effect on angiogenesis. Med Sci Monit 6:1047-1052 Medline.

13. Jakóbisiak M (1996) Immunology. Warsaw: Polish Scientific Publishers

14. Aderka D, Engelmann H, Shemer-Avni Y, Hornik V, Galil A, Sarov B, Wallach D (1992) Variation in serum levels of the soluble TNF receptors among healthy individuals. Lymph Cyt Res 11:157-159. 
15. Inoue $Y$,

King TE Jr,

Barker E,

Daniloff E,

Newman LS

(2002) Basic

fibroblast growth factor and its receptors in idiopathic pulmonary fibrosis and lymphangioleiomyomatosis. Am J Respir Crit Care Med 166:765-773 Medline. doi:10.1164/rccm.2010014

16. Jimenez-Boj E, Kedersha N, Tohidast-Akrad M, Karlhofer FM, Stummvoll G, Zimmermann C, Ulrich W, Guiducci S, Hoefler E, Aringer M, Schett G, Matucci-Cerinic M, Smolen JS, Steiner G (2008) Autoantibodies to the translational suppressors T cell intracytoplasmic antigen 1 and $\mathrm{T}$ cell intracytoplasmic antigen 1-related protein in patients with rheumatic diseases: increased prevalence in systemic lupus erythematosus and systemic sclerosis and correlation with clinical features. Arthritis Rheum 58:1226-1236 Medline. doi:10.1002/art.23435

17. Al-Mutairi S, Al-Awadhi A, Raghupathy R, Al-Khawari H, Sada P, Al-Herz A, Rawoot P (2007) Lupus patients with pulmonary involvement have a pro-inflammatory cytokines profile. Rheumatol Int 27:621-630 Medline. doi:10.1007/s00296-006-0268-3

18. Sabry A, Sheashaa H, El-Husseini A, Mahmoud K, Eldahshan KF, George SK, AbdelKhalek E, El-Shafey EM, Abo-Żenah H (2006) Proinflammatory cytokines (TNF-alpha and IL-6) in Egyptian patients with SLE: its correlation with disease activity. Cytokine 35:148-153 Medline. doi:10.1016/j.cyto.2006.07.023

19. Sezar O, Jakob C, Eucker J, Niemöller K, Gatz F, Wernecke K-D, Possinger K (2001) Serum levels of the angiogenic cytokines basic fibroblast growth factor (bFGF), vascular endothelial growth factor (VEGF) and hepatocyte growth factor (HGF) in multiple myeloma. Eur J Haematol 66:83-88 Medline. doi:10.1034/j.1600-0609.2001.00348.x

20. Kadono T, Kikuchi K, Kubo M, Fujimoto M, Tamaki K (1996) Serum concentrations of basic fibroblast growth factor in collagen diseases. J Am Acad Dermatol 35:392-397 Medline. doi:10.1016/S0190-9622(96)90603-9

21. Antony VB, Nasreen N, Mohammed KA, Sriram PS, Frank W, Schoenfeld N, Loddenkemper R (2004) Talc pleurodesis: basic fibroblast growth factor mediates pleural fibrosis. Chest 126:1522-1528 Medline. doi:10.1378/chest.126.5.1522

22. Robak E, Woźnicka A, Sysa-Jędrzejowska A, Stępień H, Robak T (2002) Circulating angiogenesis inhibitor endostatin and positive endothelial growth regulators in patients with systemic lupus erythematosus. Lupus 11:348-355 Medline. doi:10.1191/0961203302lu199oa

23. Piorunek T (2007) Diffusing capacity of the lung for carbon monoxide (DLCO). Przew Lek supl 1: 55-56. 
Table 1. Serum concentrations of cytokines (VEGF, sVEGF R1, sVEGF R, TNF- $\alpha$, TGI negative and HRCT- positive SLE subgroups and in the control

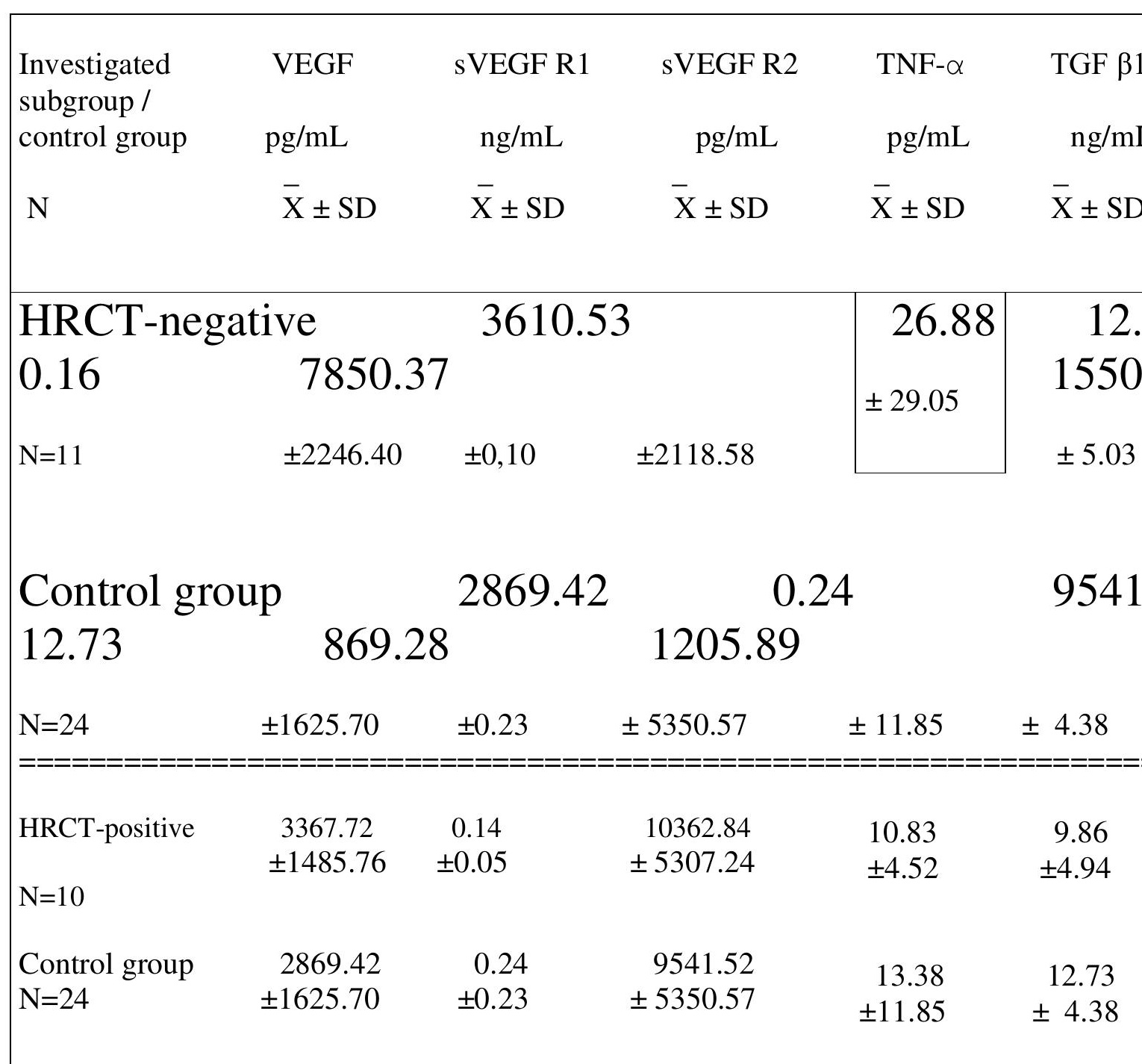


Table 2.

Correlation coefficient (Pearson's , $r$ ") between TNF- $\alpha$ and serum concentrations of othe investigated in the total group of SLE patients and HRCT- negative and HRCT- positive

\begin{tabular}{|lccccc}
\hline \multicolumn{5}{c}{ Pearson's „r” } \\
TNF- $\alpha$ & VEGF & sVEGF R1 & sVEGF R2 & TGF $\beta 1$ & bFGF \\
Study group / \\
subgroup \\
N
\end{tabular}


icient (Pearson's , r") between DLCO and serum concentrations of growth factors and soluble otal group of SLE patients and HRCT- negative and HRCT- positive subgroups

Pearson's „,r”

VEGF $\quad$ sVEGF $1 \quad$ sVEGF $2 \quad$ TNF- $\alpha \quad$ TGF $\beta 1 \quad$ bFGF $\quad$ HGF

\begin{tabular}{|c|c|c|c|c|c|c|}
\hline 0.2322 & -0.00 & 2776 & $\begin{array}{r}-0.3109 \\
-0.26\end{array}$ & \multicolumn{2}{|c|}{-0.1784} & - \\
\hline-0.1201 & -0.4622 & -0.3645 & -0.3020 & -0.0155 & -0.3661 & -0.2771 \\
\hline 0.1312 & -0.1801 & -0.0783 & -0.4570 & 0.3921 & -0.2461 & -0.3401 \\
\hline
\end{tabular}

